\title{
The role of diatomite as a detoxifying agent in soil contamination with copper
}

\author{
Alevtina Kulikova ${ }^{1}$, Vitaly Isaichev ${ }^{1}$, Andrey Kozlov $^{2}$, and Olga Tsapovskaya ${ }^{1, *}$ \\ ${ }^{1}$ P.A. Stolypin Ulyanovsk State Agrarian University, Ulyanovsk, Russia \\ ${ }^{2}$ FSBEI VE Minin State Pedagogical University of Nizhny Novgorod, Nizhny Novgorod, Russia
}

\begin{abstract}
The article presents the results of studying the toxic levels of mobile copper in typical chernozem by doing model field experiments with artificial soil contamination with copper sulfate at a level of 2 MPC $\mathrm{Cu}, 4$ $\mathrm{MPC} \mathrm{Cu}$ and $10 \mathrm{MPC} \mathrm{Cu}$. It was shown that this increased the content of mobile copper from $1.4(2 \mathrm{MPC} \mathrm{Cu})$ to 2.0 times $(10 \mathrm{MPC} \mathrm{Cu})$ when copper was extracted from the soil, respectively, with an acetateammonium buffer solution of $\mathrm{pH} 4.8$ and $1 \mathrm{n} \mathrm{HCl}$ solution. The latter was accompanied by the loss of almost a third of the spring wheat yield (29\%) and an increase in the entry of the element into produce (grain). The application of diatomite to the soil (dose $5 \mathrm{t} / \mathrm{ha}$ ) as a detoxifying agent contributed to a decrease in the level of copper in the spring wheat produce by $8(2 \mathrm{MPC} \mathrm{Cu})$ and $35(10 \mathrm{MPC} \mathrm{Cu}) \%$.
\end{abstract}

\section{Introduction}

At present, due to a significant intensification of anthropogenic impact on the environment, there is an accelerated build-up of the content of heavy metals in soils, which are usually classified as elements with atomic masses of more than 50 at. units [1]. Among the chemical elements, heavy metals are the most toxic ones and, in terms of hazard, they are only less toxic than pesticides (and some exceed them) [2]. Many of them in ultra micro and micro amounts are necessary for the normal growth and development of plants, since they are part of various enzymes and actively participate in metabolic processes. However, if they are present in excessive concentrations in the environment, including soil, they can have a strong toxic effect. Copper is one of the most significant representatives in this respect.

Copper $(\mathrm{Cu})$ is one of the trace elements that plants absolutely need. The physiological role of copper is determined by the fact that it is in the composition of vital enzymes: polyphenol oxidase, lactase, ascorbate oxidase, nitrite reductase, hyponitrite reductase and nitric oxide reductases, etc. Copper-containing enzymes carry out oxidation reactions by transferring electrons, have influence on the biosynthesis of leghemoglobin by increasing the process of binding molecular nitrogen of the atmosphere by legumes, have an effect on the structure and function of nucleic acids [3,4].

Its role in metabolic processes is due to its specific physicochemical properties:

\footnotetext{
*Corresponding author: volkova-ivinaelena@yandex.ru
} 
- copper ions form stable complexes with amino acids, proteins and other biopolymers to a greater extent than other metals;

- copper ions have catalytic properties that are enhanced when the ion is bound to a protein molecule;

- a copper ion can behave either as a donor or as an electron acceptor, since it easily releases or accepts one electron [3].

The participation of copper in the protective function of the plant organism is widely known. This function increases drought and cold resistance of plants, reduces the susceptibility of plants to smut and rust, mildew. High concentrations of copper are manifested in the form of metallotoxicosis: chlorosis, necrosis, inhibition of the growth of roots and shoots, up to the complete death of the plant, which is due to a decrease in the activity of a number of enzymes [4]. Therefore, it is extremely important to assess the levels of this element in soils, the degree of its mobility and toxicity, to develop agrotechnical methods that help reduce the content of heavy metals, in particular copper, in crop produce. The foregoing determined the goal of our study - to establish the levels of mobile copper in typical chernozem, leading to produce contamination and the role of diatomite (high-silica rock) as a detoxifying agent.

\section{Objects and methods of research}

The studies were carried out by doing model field experiments using artificial soil contamination with copper sulfate at the level of $2 \mathrm{MPC}, 4 \mathrm{MPC}$ and $10 \mathrm{MPC} \mathrm{Cu}$. The experimental design included 8 variants: 1 . Control, 2. Application of copper sulfate to the soil at a concentration of $2 \mathrm{MPC}, 3.4 \mathrm{MPC} \mathrm{Cu}, 4.10 \mathrm{MPC} \mathrm{Cu}, 5$. Diatomite at a rate of $5 \mathrm{t}$ / ha, 6. Diatomite $+2 \mathrm{MPC} \mathrm{Cu}, 7$. Diatomite $+4 \mathrm{MPC} \mathrm{Cu}, 8$. Diatomite $+10 \mathrm{MPC} \mathrm{Cu}$. The area of one plot is $1 \mathrm{~m}^{2}$, their location is randomized, the experiment is repeated 4 times according to the methodological requirements [5].

One of the most effective measures to eliminate the consequences of high concentrations of contaminants when getting into the soil, including heavy metals, is the conversion of their readily soluble compounds into hardly soluble ones, which makes it possible to reduce their availability to plants. For this purpose, it is possible to use natural substances with a high sorption capacity, including high-siliceous rocks (diatomites, zeolites, bentonites and other clays), which are widespread in nature, environmentally friendly and have soil-improving properties [6,7,8]. Their agronomic, ecological and economic effectiveness has been proved in a number of works $[9,10]$. The ability of monosilicic and polysilicic acids, present in amorphous silica of siliceous rocks, has also been proved to precipitate heavy metals into insoluble compounds [11, 12, 13,14,15].

The experimental crop was spring wheat Margarita selected by the Ulyanovsk Research Institute of Agriculture. The soil of the experimental field is typical medium-loamy, medium-thick chernozem characterized by the following parameters: humus content $4.7 \%$, available phosphorus $196 \mathrm{mg} / \mathrm{kg}$ (high supply according to Chirikov, extracted from the soil with a solution of $0.5 \mathrm{n} \mathrm{COOH}$ ), potassium $206 \mathrm{mg} / \mathrm{kg}$ (very high supply, determined with the same solution), the reaction of the soil solution is neutral with $\mathrm{pH}_{\mathrm{KCl}} 6.7$ units.

Mobile copper was determined using two methods: by extracting it from the soil with an acetate-ammonium buffer solution with $\mathrm{pH}$ of 4.8 units (AAB) (GOST R50684-94) and 1n hydrochloric acid solution (GOST RD 5218.286-91). The first method, according to the Decree of the Chief Sanitary Doctor of the Russian Federation of 23.01.2006 No. 1 "On the introduction of hygienic standards HS 21.7.2041-06", established the maximum permissible concentration (MPC) of mobile copper in soils $-3.0 \mathrm{mg} / \mathrm{kg}$ of soil. The second method is used by the agrochemical service of the country to determine the supply of soils with this element. 
All analyses of soil and plant samples were carried out in the accredited laboratory of FSBEI "SAS" Ulyanovskaya "(N: RA.RU. 510251).

\section{Results and their discussion}

The results of determining mobile (available) copper compounds in the soil of the experimental plot are presented in Table 1 .

Table 1. The content of mobile copper in the arable layer depending on the level of contamination and the application of diatomite, $\mathrm{mg} / \mathrm{kg}$ (Soil samples were taken at the end of the crop vegetation period).

\begin{tabular}{|c|c|c|c|c|}
\hline \multirow{2}{*}{ Variant } & \multicolumn{2}{|c|}{$\begin{array}{c}\text { Cu extracted with the } \\
\text { solution of AAB }\end{array}$} & $\begin{array}{c}\text { Cu extracted with the solution } \\
\text { of 1n HCI }\end{array}$ \\
\cline { 2 - 5 } & content & $\begin{array}{c}\text { deviation } \\
\text { from control }\end{array}$ & content & $\begin{array}{c}\text { deviation from } \\
\text { control }\end{array}$ \\
\hline Control & 0.19 & - & 8.50 & - \\
\hline $2 \mathrm{MPC} \mathrm{Cu}$ & 0.27 & +0.08 & 8.70 & +0.20 \\
\hline $4 \mathrm{MPC} \mathrm{Cu}$ & 0.30 & +0.11 & 11.70 & +3.20 \\
\hline $10 \mathrm{MPC} \mathrm{Cu}$ & 0.36 & +0.17 & 15.90 & +7.40 \\
\hline Diatomite & 0.10 & -009 & 7.30 & -1.20 \\
\hline Diatomite + 2 MPC Cu & 0.14 & -0.05 & 8.00 & -0.50 \\
\hline Diatomite + 4 MPC Cu & 0.29 & +0.10 & 9.10 & +0.60 \\
\hline Diatomite + 10 MPC Cu & 0.36 & +0.17 & 13.80 & +5.30 \\
\hline LSD 05 & 0.03 & & 0.70 & \\
\hline MPC & 3.00 & & 3.00 & \\
\hline
\end{tabular}

The data in the table show that when determining heavy metals by extracting from the soil with an acetate-ammonium buffer solution with $\mathrm{pH}$ of 4.8 units, the concentration of available copper is almost 10 times lower than its maximum permissible amounts. Consequently, judging by this indicator, the threat of contamination of produce with this element is completely non-existent, while the analysis of spring wheat production showed that this is far from the case.

However, a completely different picture was observed when copper was extracted from the soil with the solution of $1 \mathrm{n}$ hydrochloric acid $(1 \mathrm{n} \mathrm{HCl})$. It is this procedure that is used by the agrochemical service of the country to assess the degree of soil supply with trace elements, including copper. At the same time, the content of mobile copper in the arable layer of less than $1.5 \mathrm{mg} / \mathrm{kg}$ belongs to the group of average supply with this element, more than $3.3 \mathrm{mg} / \mathrm{kg}$ - to the high group. Consequently, it is the content of mobile copper in the soil, extracted with 1n hydrochloric acid solution, that characterizes the potential threat of produce contamination.

The data in Table 1 indicate that the content of mobile copper in the soil of the experimental field when it is extracted with $1 \mathrm{n} \mathrm{HCl}$ is high and exceeds the MPC by $3.5 \mathrm{mg}$ $/ \mathrm{kg}$. A particularly strong change in the content of potentially available copper compounds occurred when it was applied to the soil in a soluble form in amounts corresponding to 4 and $10 \mathrm{MPC}$ and amounted to 11.7 and $15.9 \mathrm{mg} / \mathrm{kg}$ in contrast to natural fertilization and 9.10 and $13.8 \mathrm{mg} / \mathrm{kg}$ - after application of diatomite. Similar regular changes in the content of mobile copper were also noted when the element was extracted with a softer 
reagent, an acetate-ammonium buffer solution: in contamination of $10 \mathrm{MPC} \mathrm{Cu}$, it almost doubled.

The use of diatomite in the soil as a detoxifying agent made it possible to reduce the mobility of copper significantly in relation to the control variant: almost 2 times when extracting it with $\mathrm{AAB}$ and 1.2 times when extracting with $1 \mathrm{n} \mathrm{HCl}$. In contrast to copper contamination, the use of diatomite contributed to a decrease in mobility, therefore, its availability to a level of 2 MPC of $\mathrm{Cu}$. However, with a higher contamination level of 4 and $10 \mathrm{MPC} \mathrm{Cu}$, the threat that the metal will get into the produce remains. The decrease in the mobility of copper in the soil after applying diatomite is undoubtedly due to the presence of amorphous silica (as mentioned above) and the ability of monosilicic and polysilicic acids to form poorly soluble silicates with heavy metals, including copper, according to the type $2 \mathrm{Cu}^{2}++\mathrm{SiO}^{4}+4=\mathrm{Cu}_{2} \mathrm{SiO}^{4}$. Thus, diatomite is a natural sorbent, an effective means of reducing the mobility of heavy metals in the soil.

Thus, when assessing agricultural lands contaminated with heavy metals (in this case, with copper), it is necessary to take account of not only soluble compounds of the element, but also less mobile, but potentially hazardous ones from the point of view of their uptake by plants, extracted from the soil with single-normal solutions of acids $\left(\mathrm{HCl}\right.$ or $\left.\mathrm{HNO}^{3}\right)$.

To form high yields and obtaining ecologically clean high-quality products, it is necessary to create optimal conditions for growth and development, not only in terms of nutritional regimes, moisture supply, etc., but also the absence of negative factors, which are the presence of various toxic substances in the soil including heavy metals. The figure shows the grain yield of spring wheat depending on the level of copper contamination.

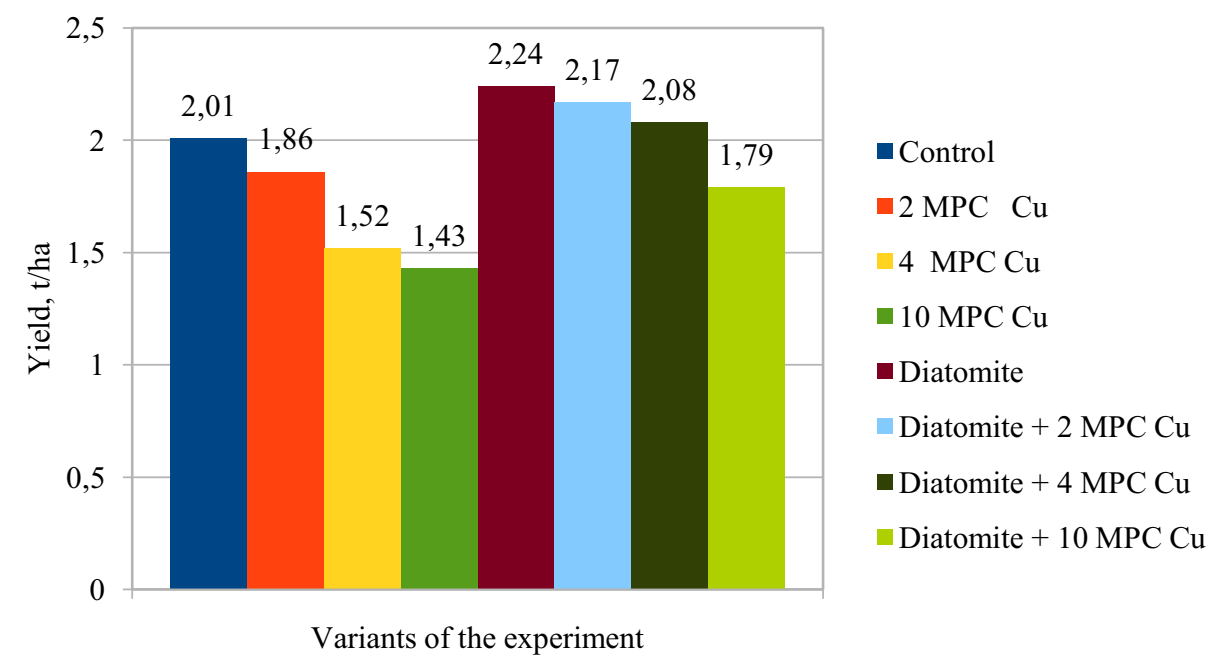

Fig. 1. Yield of spring wheat grain depending on the level of copper contamination.

The results of field experiments showed a significant decrease in the grain yield of spring wheat when the soil is contaminated with copper at the level of 4 and $10 \mathrm{MPC} \mathrm{Cu}$ (by 24 and 29\%). At the same time, high concentrations of copper in the soil environment lead not only to the inhibition of the growth and development of the root system, but also to a reduction in the supply of nutrients in plant and a disproportion of their ratio [11].

The use of diatomite in the soil at a dose of $5 \mathrm{t} /$ ha practically neutralized the negative effect of copper on the formation of the yield of spring wheat grain to a contamination level of $4 \mathrm{MPC} \mathrm{Cu}$. However, at higher copper concentrations (up to $10 \mathrm{MPC} \mathrm{Cu}$ ), it was not possible to completely block the toxic effect of copper by applying diatomite, and the yield decreased in relation to the control group by $0.22 \mathrm{t} / \mathrm{ha}$, or by $11 \%$. 
Special attention should be paid to the results obtained in the variant with the use of pure diatomite, where the grain yield of spring wheat increased by $0.23 \mathrm{t} /$ ha. Undoubtedly, this is due to the favorable influence of the rock on the properties of the soil and the state of crops due to its unique properties (adsorption, catalytic, ion-exchange, protective). According to our data, high-siliceous rocks, in this case diatomite, at a dose of $5 \mathrm{t} / \mathrm{ha}$, had a structure-forming and loosening effect on the soil, which was accompanied by an increase in its biogenicity by $20-30 \%$ and, as a consequence, the content of mineral forms of nitrogen by $16-23 \mathrm{mg} / \mathrm{kg}$, available phosphorus and potassium per $23-52 \mathrm{mg} / \mathrm{kg}$ of soil [9].

Diatomite contributed not only to an increase in crop yields, but also to the production of ecologically clean products. Table 2 shows data characterizing the copper content in the grain of spring wheat, depending on the level of soil contamination with it and the use of diatomite as a detoxifying agent.

Table 2. The content of copper in the grain of spring wheat, depending on the level of soil contamination with it and the use of diatomite as a detoxifying agent.

\begin{tabular}{|c|c|c|c|}
\hline \multirow{2}{*}{ Variant } & \multirow{2}{*}{ Content. $\mathrm{mg} / \mathrm{kg}$} & \multicolumn{2}{|c|}{ Deviation from the control group. \pm} \\
\hline & & $\mathrm{mg} / \mathrm{kg}$ & $\%$ \\
\hline Control & 0.60 & - & - \\
\hline $2 \mathrm{MPC} \mathrm{Cu}$ & 0.70 & +0.10 & +17 \\
\hline $4 \mathrm{MPC} \mathrm{Cu}$ & 0.78 & +0.18 & +30 \\
\hline $10 \mathrm{MPC} \mathrm{Cu}$ & 0.90 & +0.30 & +150 \\
\hline Diatomite & 0.50 & -0.10 & -17 \\
\hline Diatomite $+2 \mathrm{MPC} \mathrm{Cu}$ & 0.65 & +0.05 & +8 \\
\hline Diatomite $+4 \mathrm{MPC} \mathrm{Cu}$ & 0.71 & +0.11 & +18 \\
\hline Diatomite $+10 \mathrm{MPC} \mathrm{Cu}$ & 0.81 & +0.21 & +35 \\
\hline $\mathrm{HCP}_{05}$ & 0.05 & & \\
\hline
\end{tabular}

As follows from the data in the table, on the contaminated soil, the uptake of copper by the produce significantly increased and its accumulation in the grain with the content in the soil at the level of contamination of $10 \mathrm{MPC} \mathrm{Cu}$ was 1.5 times higher than in the control group. The application of diatomite in the soil made it possible to reduce the level of copper in grain in relation to the corresponding variant by $10 \%$ (from $0.90 \mathrm{mg} / \mathrm{kg}$ to $0.81 \mathrm{mg} / \mathrm{kg}$ ).

\section{Conclusions}

1. Against the background of artificial contamination with copper, the content of its mobile compounds significantly increased: from $1.4(2 \mathrm{MPC} \mathrm{Cu})$ to 2.0 times $(10 \mathrm{MPC})$ when extracted from the soil with an acetate buffer solution $(\mathrm{pH} 4.8)$ and, accordingly, from 1.3 to 1.9 times - their determination with $1 \mathrm{n} \mathrm{HCl}$.

2. Copper contamination even at the level of $2 \mathrm{MPC} \mathrm{Cu}$ can lead to the yield loss, and with a higher content of its mobile forms (up to $10 \mathrm{MPC} \mathrm{Cu}$ ) - almost the loss of a third of the yield (up to 29\%). Consequently, the toxic effect of copper begins to manifest itself when its content in the soil is at the level of $2 \mathrm{MPC} \mathrm{Cu}$.

3. The application of diatomite to the soil at a rate of $5 \mathrm{t} /$ ha was accompanied by a decrease in the amount of mobile copper in the arable layer of typical chernozem by $49 \%$ extracted with an $\mathrm{AAB}$ solution and $14 \%$ extracted with $1 \mathrm{n} \mathrm{HCl}$. The latter was 
accompanied by a decrease in the uptake of copper in the spring wheat produce by 8 ( 2 $\mathrm{MPC} \mathrm{Cu}$ ) to $35 \%$ (10 MPC). Consequently, high-siliceous rocks, in this case diatomite, are an effective means of both increasing the yield of agricultural crops and obtaining ecologically safe produce.

\section{References}

1. N. Barsova, O. Yakimenko, I. Tolpeshta, G. Motuzova, Environmental pollution, 200207 (2019)

2. E. Frieden, I. Alles, Biol. Chem. 200, 153-178 (1968)

3. M.Ya. Shkolnik, Trace elements in plant life (Publishing house "Science", 1974)

4. I.N. Semyonova, G.Sh. Singizova, A.B. Zulkaranaev, G.Sh. Ilbulova, Contemporary problems of science and education 3, 15-20 (2015)

5. B.A. Dospekhov, Field experiment methodology (with the basics of statistical processing of research results) (Book on demand, M., 2012)

6. O. Abollino, A. Giacomino, M. Malandrino, E. Mentasti, Applied Clay Sience 38, 227 236 (2008)

7. O. Abollino, A. Giacomino, M. Malandrino, E. Mentasti, Water, Air, Soil Pollution 181, 149-160 (2007)

8. S.E. Bailey, T.J. Olin, D.D. Adrian, Water Res. 33(11), 2469-2479 (1999)

9. A.Kh. Kulikova, Silicon and high-siliceous rocks in the fertilization system of agricultural crops: monograph (USAA, Ulyanovsk, 2013)

10. A. Kulikova, A. Kozlov, N. Zakharov, E. Yashin, N. Khairtdinova, International Scientific-Practical Conference "Agriculture and Food Security: Technology, Innovation, Markets, Human Resources" 17 (2020)

11. Yu.S. Belousova, The condition of copper and zinc in the "soil-plant" system under contamination conditions: abstract of the Ph.D thesis in Biology (Agrochemistry, M., 2013)

12. V.V. Matichenkov, D. Culvert, G.H. Shyder et al., Proc. $7^{\text {th }}$ Inter. Conf. Wetland Systems for Water Pollution Control., 30-36 (Lake Buena Vista, Florida, 2000)

13. M. Adrees et al, Ecotoxicology and Environmental Safety 119, 186-197 (2015)

14. J.A. Bhat, et al, Plants 8(3), 71 (2019)

15. V.V. Matychenkov, The role of mobile silicon compounds in plants and the soilplant system: dis. ... dr. biologist. Sciences (Pushchino, 2008) 